\title{
SARCÓFAGOS TARDOANTIGUOS EN LA BÉTICA ORIENTAL: DECORACIÓN Y MORFOLOGÍA
}

\author{
JUAN CARLOS OLIVERA DELGADO \\ Universidad de Granada
}

\begin{abstract}
Resumen
Los trabajos publicados sobre sarcófagos tardoantiguos han evolucionado desde el siglo XX. Paulatinamente se han divulgado estudios más centrados en la iconografía y la estética, pero que no aportan una visión de conjunto sobre las medidas, ornamentación y material dentro de una misma zona geográfica. Este estudio pretende aglutinar el mayor número posible de datos artísticos, métricos e iconográficos sobre los sarcófagos localizados en la Bética oriental con el fin de aportar una nueva visión global de estas piezas tardo antiguas.

Palabras clave

Antigüedad Tardía, Andalucía, Bética oriental, Sarcófago, Iconografía, visigodos.
\end{abstract}

\section{OLD LATE SARCOPHAGOS IN EASTERN BÉTICA: DECORATION AND MORPHOLOGY.}

\section{Summary}

Published works on late sarcophagi have evolved since the 20th century. Gradually, more studies focused on the iconography and aesthetics have been published, but they do not carry out an overview of the measures, ornamentation and material within the same geographical area. This study aims to gather the largest number of data (artistic, metric, iconographic) on the sarcophagi located in eastern Bética in order to provide a new overview of these lateancient pieces.

$$
\text { Keywords }
$$

Late Antiquity, Andalusia, Eastern Betica, Sarcophagus, Iconography, Visigoths. 


\section{Introducción}

Debido a su carácter ritual relacionado con la otra vida, los sarcófagos posiblemente son, junto a las lucernas, las piezas más antiguas del cristianismo. Durante el siglo XX Pedro de Palol, al igual que el profesor Sotomayor Muro, hizo un estudio en profundidad, aunque también existen otras investigaciones más recientes. Mediante este artículo se pretende estudiar y resaltar las formas externas y simbólicas de los sarcófagos encontrados en la Bética oriental pertenecientes al periodo cronológico de los siglos IV-VIII, ya que pueden aportar datos diferentes a los conocidos hasta el momento.

La puesta en valor de tablas que recogen aspectos como las medidas, el material en el cual están realizados o la representación iconográfica de los mismos, ponen de relevancia datos que anteriormente solo eran mencionados y que a partir de este estudio estarán accesibles para futuras investigaciones.

\section{Historiografía}

El hallazgo en 1884 del sarcófago de Alcaudete, en Jaén, puede considerarse el detonante, en la Bética, de los primeros estudios científicos en este campo. Al igual que el del resto de los sarcófagos aquí catalogados, su hallazgo fue casual. En concreto, este se encontró en pésimas condiciones en un establo. Dos años más tarde, en la Bética occidental, aparece adosado al muro norte de la iglesia de Santa Cruz en Écija, Sevilla, otro sarcófago romano cristiano.

Los estudios comienzan a proliferar. En 1887 se publica el primer artículo sobre el sarcófago de Écija, escrito por Manuel Sales y Ferré: "Estudios Arqueológicos e Históricos. Necrópolis de Carmona. Funerales romanos y sus creencias acerca del alma y de la otra vida. Sarcófago visigótico de Écija. Excursión al Aljarafe". ${ }^{1}$ Paralelamente, el padre F. Fita publicó "Sarcófago cristiano de Écija”." Las publicaciones sobre los sarcófagos béticos se suceden desde ese momento, destacando la obra de J. Ficker Die christlichen Sarkophage Spaniens. ${ }^{3}$

A finales del siglo XIX, en 1896, durante la remodelación del antiguo Molino del Rey en Martos, Jaén, aparecerá en óptimo estado de conservación el sarcófago columnado de Martos, y solo unos años más tarde, en 1923, se halla el sarcófago marmoleo de la localidad de Berja, en Almería.

Estos hallazgos en la Bética pusieron de manifiesto la olvidada y rica etapa de la tarda antigüedad. Desde ese momento, y a lo largo del siglo XX, surgirán estudios científicos de gran valor para la Bética y el resto de la Península destacando, entre otros, los de H. Schlunk Die Sarkophage von Ecija und Alcaudete (1962), ${ }^{4}$ donde hace una descripción y comparación de sobre los sarcófagos de Écija y Alcaudete; la importante aportación del profesor Palol para la Antigüedad Tardía Arqueología Cristiana de la España Romana siglos IV-VI (1967) $)^{5}$ o la publicación de M. Sotomayor Sarcófagos romano-cristianos preconstantinos en España (1975). ${ }^{6}$

El interés por estas piezas monumentales sigue siendo objeto de estudio en la actualidad, como lo demuestra los recientes artículos de Cueves, "Los sarcófagos paleocristianos del sudeste español", 7 Flórez García, "Los sarcófagos de Begastri. Catálogo actualizado (2019), ${ }^{8}$ o Franco Mata, "El sarcófago paleocristiano de Astorga en el Museo Arqueológico Nacional", entre otros.

La presencia de sarcófagos cristianos durante la Antigüedad Tardía es algo patente en Hispania y, en particular, en el sur peninsular. Existen dos magníficos ejemplares historiados en la provincia de Jaén, así como dos ejemplos más con decoración geométrica en Arjona, además del sarcófago de Berja, en Almería. Sin embargo, pese a existir en ella diverso material tardo antiguo cristiano,

\footnotetext{
${ }^{1}$ Sales y Ferre, 1887.

2 Fita, 1887: 267.

${ }^{3}$ Kicker, 1887: 87-88.

${ }^{4}$ Schlunk, 1967: 119-151.

${ }^{5}$ Palol, 1967: 276

${ }^{6}$ Sotomayor, 1975.

${ }^{7}$ Cueves, 2007: 442-449.

${ }^{8}$ Flórez García, 2019: 235-248. Tomaremos como ejemplo la descripción que realiza de los distintos fragmentos de los sarcófagos para la elaboración de nuestro artículo, ya que engloba aspectos cuantitativos y descriptivos que aportan una valiosa información.

${ }^{9}$ Franco Mata, 2020: 4-10.
} 
no se cuenta con ningún ejemplar en la provincia de Granada. ${ }^{10}$ Puede que la escasez en este campo se deba a que, como bien señaló el profesor Miguel Ángel García, "la destrucción parcial o total de los sarcófagos romanos a manos de la población hispanomusulmana durante el periodo andalusí es uno de los periodos más característicos relacionados con la presencia de este tipo de objetos en el sur peninsular", ${ }^{11}$ o, por el contrario, a la no aparición de los mismos.

La destrucción de los sarcófagos y de cualquier objeto que representara vida animal o humana corresponde a ciertos periodos de intolerancia y de violencia material por parte de la población hispanomusulmana hacia estos objetos religiosos. La reutilización de los sarcófagos cristianos, al igual que el cristianismo hizo con piezas y templos paganos, propició, desgraciadamente, la desaparición de un número indeterminado de piezas que desconocemos. Siguiendo la clasificación del doctor García García, se pueden encontrar cuatro tipos de reutilizaciones: la reutilización de los sarcófagos con finalidad funeraria, la reutilización de las cajas de los sarcófagos para usos distintos al original, el reaprovechamiento de piezas como elementos arquitectónicos y, finalmente, la utilización de los fragmentos como material de acarreo. ${ }^{12}$

"La problemática a la hora de clasificarlos entre paganos o cristianos ha creado un gran número de definiciones como sarcófagos proto o criptocristianos, sarcófagos con decoración neutra, sarcófagos bucólicos o paradisíacos, amén de considerarlos únicamente paganos"13. Por su decoración, los sarcófagos se dividen en dos grandes grupos: geométricos e historiados. Los primeros cuentan, como su nombre indica, con una ornamentación basada en figuras lineales que van dibujando formas geométricas, en muchos casos asociadas a una decoración vegetal figurada. Dos ejemplos que destacar son los encontrados, en un aceptable estado de conservación, en Arjonilla, Jaén. El segundo grupo, algo más numeroso, es quizá más llamativo visualmente al estar decorados con un friso historiado con imágenes de las Escrituras, destacando los pertenecientes a Alcaudete y Martos, en Jaén, y Berja, en Almería.

\section{Sarcófagos de decoración geométrica de Arjonilla (Jaén)}

Denominación: Sarcófago de Arjonilla.

Procedencia: Arjonilla.

Depositado en: Museo de Jaén.

Descripción y valoración: El primero que se hace eco del hallazgo de una lápida cristiana encontrada en el mismo paraje donde aparecieron los sarcófagos de Arjonilla ${ }^{14}$ fue Martín de Ximena en 1644 (Vives, J., ICERV, Barcelona, 1949 (=1942, $1^{\text {a }}$ ed.) ${ }^{15}$ lo que constituye un posible indicador de la existencia de más piezas de la misma cronología en dicho yacimiento. La decoración geométrica utilizada por los nuevos pueblos germánicos asentados en el regnum gothorum se reproduce también en la fabricación de canceles y frisos, presumiblemente destinados a espacios religiosos u otros edificios civiles, por lo que también cabría la posibilidad de su uso en los sarcófagos. Esta decoración se puede observar en el friso procedente de la Guardia (Jaén), que posee similitud en sus acabados.

El trenzado, una de las técnicas más repetidas en el arte visigodo, también fue utilizada en los sarcófagos de decoración geométrica. Según el profesor Palol representaría el bautismo y las corrientes de agua del Paraíso, que dan la vida eterna ${ }^{16}$.

\footnotetext{
${ }^{10}$ En la provincia de Málaga, en el yacimiento de Singila Barba (Antequera), se encontró el fragmento de un sarcófago con la decoración "David en el foso con los leones", que estuvo depositado en la colección Casa-Loring de Málaga. Véase Schlunk, 1968: 166-182. Atienza, 1988: 92. Rodríguez, 2002: 304.

11 García García, 2004: 239-256.

12 Ídem, 2004: 244-245. Reutilización de las cajas como piletas para recoger agua o con algún uso agropecuario, así como el uso de sus componentes utilizados por el coleccionismo anticuario, como muestran los restos de sarcófagos encontrados en el conjunto califal de Madinat Al-Zahra.

También durante el medievo, se observa una reutilización con fines arquitectónicos, que responde a un doble uso; utilización de las piezas por su material o con fines ornamentales.

${ }^{13}$ García García, 2012: 184.

${ }^{14}$ Cila III: 619.

15 Vives, 1942.

16 Palol, 1956: 286-292.
} 
Los sarcófagos encontrados en Arjonilla, se realizaron en un periodo cronológico que puede indicar que fueron utilizados por cristianos. Como ya se ha mencionado anteriormente, este tipo de decoración geométrica fue muy usada por los pueblos germanos, convertidos ya al cristianismo en el periodo en que están fechados estos sarcófagos.

El primero de ellos (Fig. 1), depositado en el Museo Provincial de Jaén, está realizado en piedra arenisca, cincelado y policromado. De forma trapezoidal con tres de sus cuatro caras decoradas con formas geométricas, lo que indica que fue realizado para estar adosado a una pared o muro. En el interior hay una pequeña elevación a modo de almohada para que repose la cabeza del difunto.

Posee dos espirales ondulantes que atraviesan su cara principal, solo interrumpida por dos figuras semejantes a rosetones. En las otras dos caras la decoración se repite: espirales ondulantes y rosetones. Se desconoce el aspecto que pudo tener la tapa del sarcófago ya que se encuentra desaparecida. Destaca la largura del mismo, siendo el de mayores proporciones de los recogidos en este estudio.

Entidad: Mueble.

Caracterización: Funerario.

Material: Piedra arenisca.

Técnicas: Talla.

Medidas: 0,66 × 2,26 x 0,75x 0,10 m.

Cronología: Su cronología oscilaría entre los siglos VI y VIII, durante el pleno dominio visigodo del territo

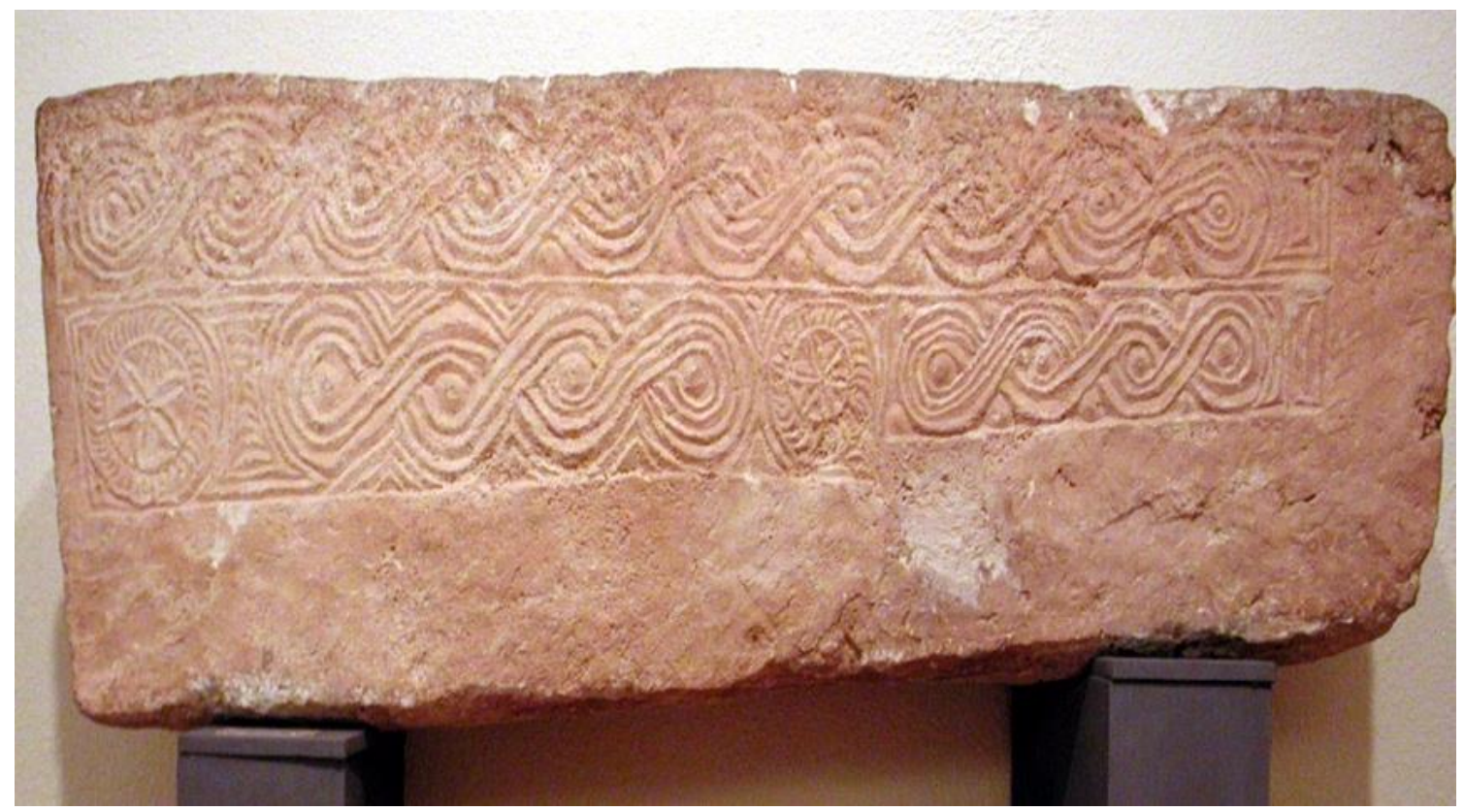

Fig. 1. Sarcófago de Arjonilla. Museo Provincial de Jaén. Fuente: José Luis Martínez Ocaña.

Denominación: Sarcófago de Arjonilla.

Procedencia: Paraje de las Herrerias (Arjonilla).

Depositado en: Parroquia Nuestra Señora de la Encarnación (Arjonilla).

Descripción y valoración:

El segundo de los sarcófagos geométricos (Fig. 2) también proviene del "Paraje de las Herrerías" y guarda muchas semejanzas con el anterior, ya que también está fabricado en piedra arenisca y ornamentado con decoración vegetal y geométrica. Actualmente se encuentra depositado en la parroquia de Nuestra Señora de la Encarnación de Arjonilla, en Jaén, donde es utilizado como mesa de altar. Esta decoración de ondas geométricas, según el profesor Palol, 
representa el agua del bautismo y el nacimiento de la nueva vida. También presenta la cara principal cinco grandes rosetones y dos de menor tamaño en el lado derecho en la cara central.

Entidad: Mueble.

Caracterización: Funerario.

Material: Piedra arenisca. Técnicas: Talla.

Medidas: $0,60 \times 2,08 \times 0,76 \mathrm{~m}$.

Cronología: VI-VII.

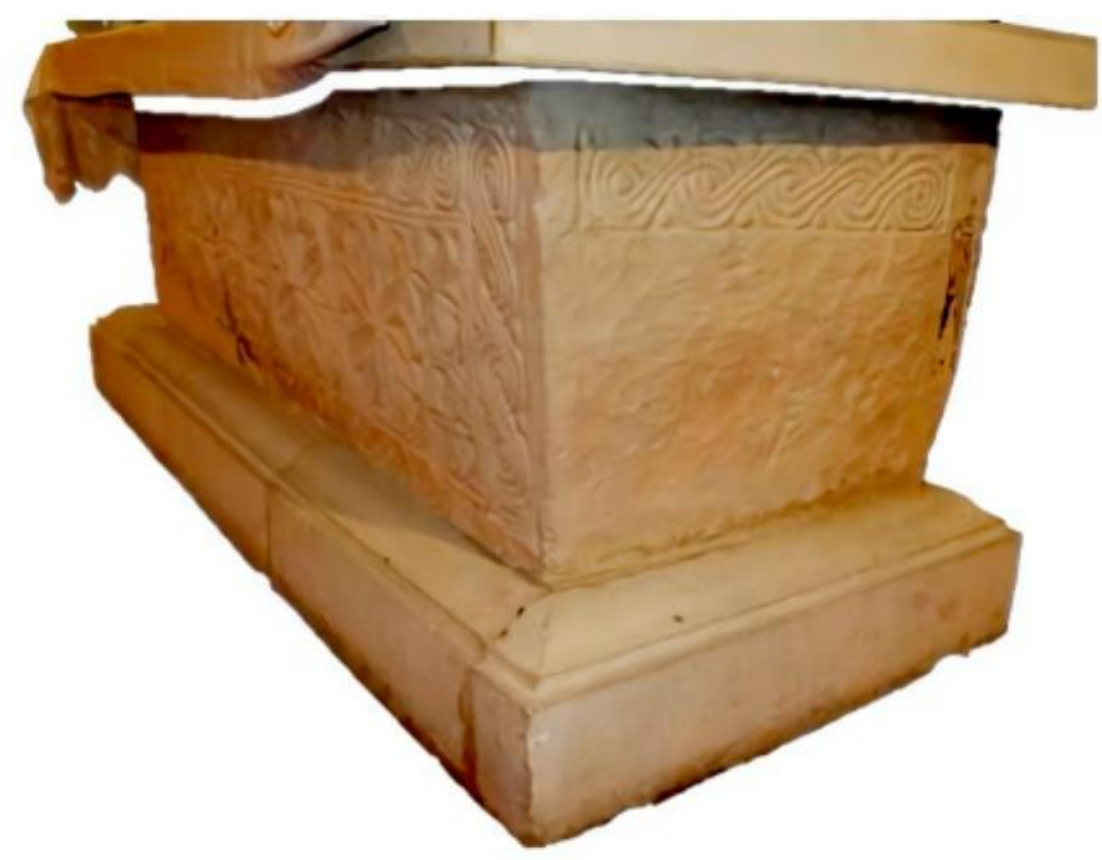

Fig. 2. Sarcófago de Arjonilla. Artículo de Verónica Arazola en http://parroquiarjonilla.webnode.es. Consultado el 21/05/2020.

\section{Sarcófagos historiados}

El frontal del sarcófago es, en todos los casos recogidos para la Bética oriental, la parte más decorada, como si hubieran sido realizados para ser expuestos de esa cara. Es el también conocido como friso historiado, ya que en él se desarrollan las escenas escultóricas o geométricas que decoran al sarcófago. Este elemento puede ser un friso corrido en el que, como su nombre indica, están todas las escenas escultóricas continuas, sin tener apenas división visual entre ellas. Como ejemplo se puede citar el de Berja, en Almería. También puede ser un friso columnado, en el que su rasgo principal es la división de las escenas decorativas por columnas, dando el aspecto de un templo bajo el que se desarrollan las distintas escenas del Antiguo y del Nuevo Testamento. Este tipo de ornamentación se puede observar en el sarcófago de Martos.

La tapa no es un elemento que aparezca siempre, y no porque carecieran de ella, sino porque no han llegado hasta nosotros debido a su destrucción o reutilización, como es el caso del sarcófago de Berja, que apareció sin su tapa original y cubierto por unas lajas.

La decoración historiada es, ciertamente, más monumental que la geométrica. Las imágenes utilizadas en la parte del friso juegan una doble función. En primer lugar, tienen un sentido adoctrinante y divulgativo de las Escrituras, un mensaje claro que va dirigido a todo aquel que pueda interpretar las formas escultóricas que lo componen. No tienen que ser exclusivamente 
escenas del Antiguo Testamento o del Nuevo, sino que se pueden intercalar. Muy recurrentes son las escenas del Buen Pastor, Jonás y la ballena o los milagros realizados por Jesús.

En segundo lugar, tienen un carácter decorativo, imperando el poder económico de la persona que encargaba la pieza sobre el gusto estético. Los sarcófagos historiados se convierten así en verdaderas obras de arte funerario, realizando funciones artísticas, evangelizadoras y mortuorias.

Denominación: Sarcófago de Alcaudete.

Procedencia: Alcaudete.

Depositado en: Museo Arqueológico Nacional.

Descripción y valoración: El sarcófago de Alcaudete es una pieza fragmentada y mal conservada, está realizado en mármol blanco granulado con vetas azuladas. Los estudios de Recio y Sotomayor y aportan información sobre cómo sería este sarcófago en su estado original. Tiene unas medidas de 56 × 125 × $5 \mathrm{cms}$, aunque al no conocer cómo era la pieza originalmente, son orientativas. La parte izquierda de la tapa tiene una gran cara que representaría a Helios o al Sol emitiendo cuatro rayos, que actualmente están fracturados. Se aprecian improntas en la cabellera de Helios/Sol y tres espigones de mármol que servían de apoyo a sus extremos, faltando uno de ellos. Esta imagen está separada de las escenas bíblicas por una enjuta con un lirio en la parte superior.

Las escenas que se representan son las de la resurrección de Lázaro, el arrepentimiento de la Magdalena, la lucha de David contra Goliat y la escena de Daniel en el foso.

Entidad: Mueble.

Caracterización: Funerario. Material: Mármol.

Técnicas: Talla.

Medidas: 56 x 125 x 5 cms. Cronología: Siglo IV (325-335).

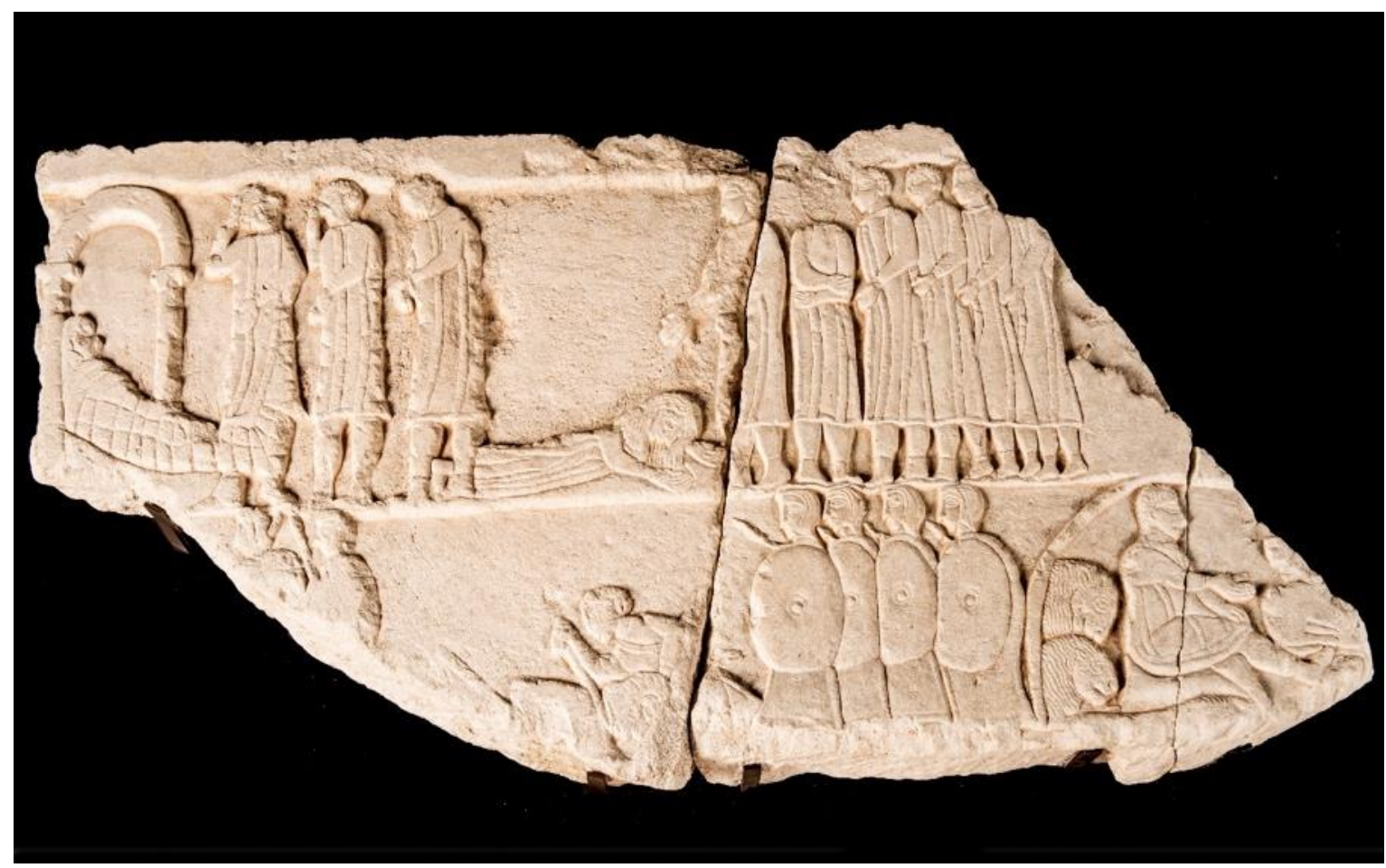

Fig. 3. Sarcófago de Alcaudete. Fuente: MAN. Ref. 500309. 
Denominación: Sarcófago de Berja.

Procedente de: Berja

Depositado en: Museo Arqueológico Nacional.

Descripción y valoración: De izquierda a derecha se observan: la resurrección de Lázaro sigue la entrada de Jesús en Jerusalén el domingo de Ramos, donde aparecen representados Cristo montado sobre un asno y Zaqueo subido a un árbol; la Orante ante los Apóstoles; el anuncio de la negación de Pedro y dos apóstoles prisioneros delante de un magistrado romano sentando. Según Sotomayor, el estilo de esta pieza, que anuncia el llamado "blando", permite fecharla hacia el año 340.

Entidad: Mueble.

Caracterización: Funerario.

Material: Mármol. Técnicas: Cincelado.

Medidas: Es de fábrica romana y presenta unas dimensiones de $0,54 \times 2,10 \times 0,6 \mathrm{~m}$. La caja interior tiene una profundidad de 0,42 $\mathrm{m}$ y una anchura de $0,40 \mathrm{~m}$ en el extremo derecho y de 0,37 $\mathrm{m}$ en el izquierdo. Las figuras tienen una anchura media, a la altura de la cintura, de 0,11 $\mathrm{m}$ y una altura media de $0,47 \mathrm{~m}$.

Cronología: Siglo IV.

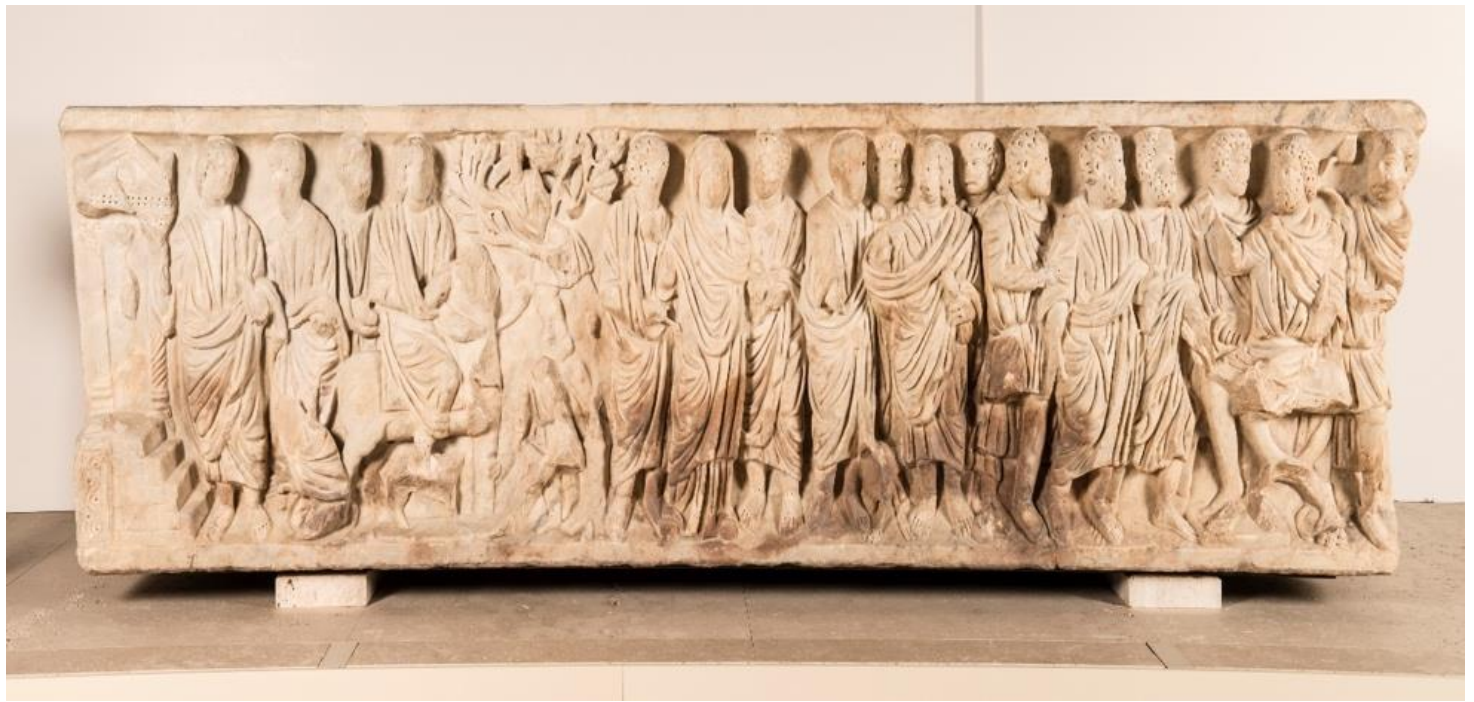

Fig.4. Sarcófago de Berja. Fuente: MAN. Ref. 1929/71/1.

Denominación: Sarcófago de Martos.

Procedencia: Martos (Molino del Rey).

Ubicación actual: Museo de Jaén.

Descripción y valoración: Sarcófago columnado de mármol blanco granulado con vetas azules. La tapa del sarcófago está decorada con dos escenas: los hebreos en el horno de Babilonia en la izquierda y la escena de Jonás a la derecha: Posee 8 columnas estriadas sobre pequeños plintos, con capiteles compuestos decorados con tres hojas de acanto, con volutas labradas como rosetas y frontones embellecidos con lirios. Está dividido en 7 nichos o intercolumnios que representan escenas distintas; la resurrección del hijo de la viuda de Naim; la curación del ciego; la curación de la Hemorroisa; el canto del gallo; la curación del paralítico; la multiplicación de los panes y los peces y la conversión del agua en vino.

Entidad: Mueble.

Caracterización: Funerario.

Material: Mármol blanco.

Técnicas: Esculpido.

Medidas: Tapa: 2,14 x 0,10 x 0,66 m. Caja: 2,14 x 0,61 x 0,66 m. Cronología: 330-337. 


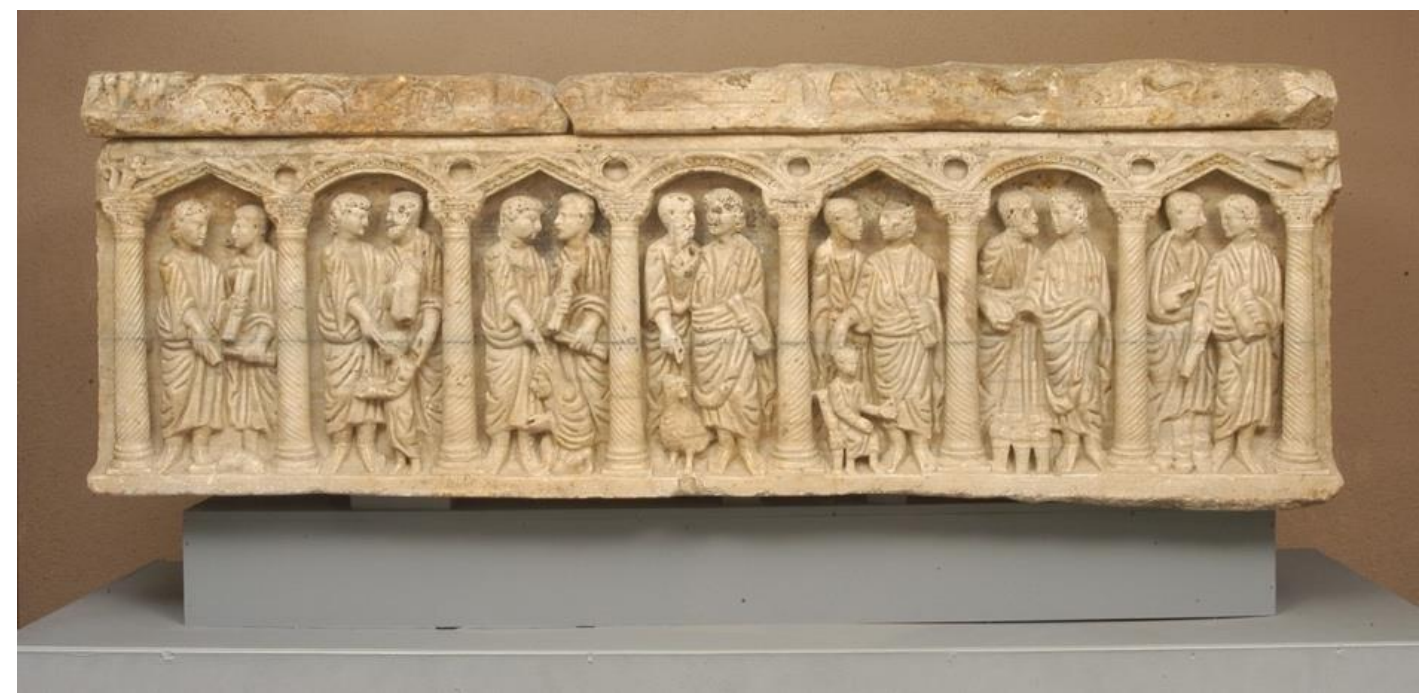

Fig.5. Sarcófago de Martos. Fuente: MAN. Ref. CE/DA01680.

\section{En cuanto a su fabricación}

Los sarcófagos tardoantiguos cristianos son, probablemente, de las piezas más monumentales del cristianismo primitivo en la Bética oriental. Ya en el siglo pasado, el profesor Palol hizo una investigación en profundidad sobre este campo y marcó las pautas de su estudio realizando una división tipológica dependiendo de su procedencia, señalando cuatro tipos: de procedencia romana, de producción en talleres hispánicos, de producción en talleres galos y de influencia bizantina.

Encuadrado en la tipología de procedencia romana se encontraría el sarcófago de Martos, ya que son muchos los autores que defienden la teoría de su importación desde un taller romano. ${ }^{17}$ García García plantea en su artículo que en el encargo para la producción de sarcófagos se pudo realizar una fabricación en serie de los mismos, debido a la gran cantidad de similitudes que ha encontrado en diferentes sarcófagos romanos contemporáneos al de Martos. ${ }^{18}$ El mismo autor remite a Ward-Perkins, ${ }^{19}$ Eichner, ${ }^{20}$ o Immerzeel ${ }^{21}$, investigadores que han amparado esta tesis.

Cabría preguntarse cuáles son las similitudes que estos autores defienden a la hora de hablar de una producción en serie. En primer lugar, las similitudes en su iconografía. Parece que los maestros escultores se especializaron en temas iconográficos que repitieron en varias de sus producciones, en el caso de que esta hipótesis sea acertada. En segundo lugar, los paralelismos decorativos, que bien pueden corresponder a un mismo taller artesanal, así como la repetición de un mismo elemento común decorativo, como por ejemplo el tritón timonel que hace sonar una caracola.

García García también cotejó la decoración de los sarcófagos de la Huerta de San Rafael (Córdoba) y Martos y, fuera de la Bética, los de los tres sarcófagos columnados de Arlés, el sarcófago de Leyden, el sarcófago columnado de Nimes y un fragmento de sarcófago que actualmente se encuentra en Ginebra. Dentro de la tipología de producción en talleres hispanos, todo apunta a que el sarcófago de Berja fue de fabricación local.

Debido a la ausencia de datos se desconoce, por el momento, si se produjeron importaciones de sarcófagos cristianos de talleres galos para la Bética oriental. Finalmente, en relación con el cuarto grupo de la tipología planteada por Palol, los de influencia bizantina, el ya mencionado sarcófago de Berja parece tener una clara influencia oriental bizantina.

\footnotetext{
17 Sotomayor, 1975: 121-127 y 146-156.

${ }^{18}$ García García, 2004: 187-191.

${ }^{19}$ Ward Perkins, 1975: 637-653.

${ }^{20}$ Eichner, 1981: 85-113.

${ }^{21}$ Immerzeel, 1996.
} 


\section{Relación de piezas}

La representación iconográfica de los sarcófagos cristianos es un programa aleccionador de escenas bíblicas en el que no hay una temática concreta, alternando imágenes del Antiguo Testamento con otras del Nuevo Testamento. ${ }^{22}$

Del Antiguo Testamento destacan las escenas relacionadas con el mensaje de salvación: la expulsión de Adán del Paraíso, escenas de Jonás, Daniel en el foso de los leones, Noé, los hebreos en el foso, el sacrificio de Isaac... Del Nuevo Testamento se incorporan milagros de Jesús como la resurrección de Lázaro o las bodas de Caná, e imágenes de la passio de Cristo. ${ }^{23}$ Constituye así un gran escenario escultórico a doctrinante que ensalza los milagros de Jesús poniéndolos en relación con el Antiguo Testamento, como herederos de la promesa mesiánica de la nueva religión cristiana.

El programa iconográfico para los sarcófagos de la Bética oriental no dista mucho del resto de los ejemplos hispanos. Se encuentran, no obstante, dos unicum dentro de la iconografía: la representación de un árbol en el sarcófago de Martos y la imagen de los apóstoles en el sarcófago de Berja.

\begin{tabular}{|c|c|c|c|c|}
\hline Biblia & $\begin{array}{l}\text { Sarcófago } \\
\text { Alcaudete }\end{array}$ & & $\begin{array}{l}\text { Sarcófago } \\
\text { Berja }\end{array}$ & $\begin{array}{l}\text { Sarcófago } \\
\text { Martos }\end{array}$ \\
\hline $\begin{array}{c}\text { Antiguo } \\
\text { Testamento. }\end{array}$ & -David y Goliat. & & & $\begin{array}{l}\text {-Jonás y la ballena. } \\
\text {-Tres jóvenes } \\
\text { hebreos en el horno. }\end{array}$ \\
\hline $\begin{array}{c}\text { Nuevo } \\
\text { Testamento }\end{array}$ & $\begin{array}{l}\text {-Arrepentimiento } \\
\text { M. }{ }^{2} \text { Magdalena, } \\
\text {-Resurrección } \\
\text { Lázaro. }\end{array}$ & de $\mathrm{de}$ & $\begin{array}{l}\text {-Resurrección de } \\
\text { Lázaro. } \\
\text {-Jesús entra en } \\
\text { Jerusalén. } \\
\text {-Orante entre } \\
\text { los apóstoles. } \\
\text {-Anuncio } \\
\text { negación Pedro. de } \\
\text {-Dos apóstoles } \\
\text { prisioneros. }\end{array}$ & $\begin{array}{l} \\
\text {-Pedro-Cristo con una } \\
\text { vara ¿resucitando? } \\
\text {-Curación de un ciego. } \\
\text {-Curación endemoniada } \\
\text {-Anuncio negación. } \\
\text {-Curación paralítico. } \\
\text {-Multiplicación } \\
\text { panes y peces. }\end{array}$ \\
\hline Grupo & & & $\begin{array}{l}\text { Grupo } \\
\text { constantiniano. }\end{array}$ & $\begin{array}{l}\text { Grupo } \\
\text { tardoconstantino. }\end{array}$ \\
\hline Tipología & Obra local & & & \\
\hline $\begin{array}{l}\text { Otros } \\
\text { Símbolos }\end{array}$ & $\begin{array}{l}\text {-Helios (Sol) } \\
\text {-Flor lilíacea }\end{array}$ & & & $\begin{array}{l}\text {-Árbol con figura } \\
\text { humana. } \\
\text {-Dos genios. }\end{array}$ \\
\hline
\end{tabular}

Cuadro 1. Decoración y representaciones en los sarcófagos. Elaboración de autor.

22 Revenga Domínguez, 2012: 107-108.

${ }^{23}$ Leal Lobón, 2011: 532-534. 


\begin{tabular}{|c|c|c|c|c|c|}
\hline SARCÓFAGO & MATERIAL & LARGURA & ANCHURA & GROSOR & DECORACIÓN \\
\hline ALCAUDETE & MÁRMOL & 0,82 & 0,46 & 0,09 & ¿Friso? \\
\hline ARJONILLA 1 & PIEDRA & 2,26 & 0,75 & 10 & Geométrica \\
\hline ARJONILLA 2 & PIEDRA & 2,08 & 0,76 & & Geométrica. \\
\hline BERJA & MÁRMOL & 2,10 & 0,57 & & Friso \\
\hline MARTOS & MÁRMOL & 2,14 & 0,66 & 10 & Columnado \\
\hline
\end{tabular}

Cuadro 2. Medidas y materiales de los sarcófagos. Elaboración de autor.

\section{Conclusiones}

Los cambios en las prácticas mortuorias con el afianzamiento del cristianismo en el imperio romano provocaron el final de la cremación de los difuntos, lo cual dio lugar al desarrollo de elementos artísticos como fueron los sarcófagos. Su producción durante la Antigüedad Tardía en la Bética oriental no sigue un patrón fijo, ya que los ejemplos historiados son más antiguos que los de decoración geométrica, fechados hasta el siglo VII. Esto se debe al continuismo inicial por parte de los pueblos germanos de la cultura del imperio. La ornamentación minuciosa y detallada de las imágenes en los frisos permite plantear la hipótesis de si su finalidad era ser enterrados bajo tierra o, por el contrario, estaban destinados a ser situados en algún panteón familiar pudiéndose admirar así su belleza.

Estas piezas, realizadas por regla general en mármol, solo podían ser adquiridas por familias adineradas pertenecientes a la clase alta hispanorromana, por lo que se pueden utilizar como indicador de desarrollo económico de las grandes villae donde fueron encontrados. La temática cristiana utilizada sigue la representación de las primeras imágenes plasmadas en las catacumbas de Roma, siendo muy recurrentes el Buen Pastor o la Orante, así como la combinación de escenas del Antiguo y Nuevo Testamento.

Cabe destacar la temática iconográfica utilizada en otros sarcófagos fechados también a comienzos del siglo IV ubicados en la provincia de Córdoba, como son el procedente de la "Huerta de San Rafael", realizado en mármol de carrara, del tipo columnado, con cinco imágenes enmarcadas entre seis columnas, donde se representa la negación de Pedro, el sacrificio de Isaac, la multiplicación de los panes y peces, así como el pecado original. Procedente de Belalcázar (Córdoba) hay una pieza muy fragmentada, de la cual solo se ha conservado la imagen de Daniel en el foso de los leones. El último ejemplo ubicado en el museo de San Vicente de la Mezquita-Catedral, realizado también en mármol, es de la tipología de friso corrido, con la representación de la Orante, la curación de la hemorroisa, la negación de Pedro y la curación del ciego.

Se puede observar que, a diferencia de otros sarcófagos realizados a comienzos de la misma centuria, los ejemplos columnados y de friso corrido en la Bética oriental recurren a pasajes milagrosos bíblicos para su decoración, a diferencia del ubicado en los museos vaticanos "sarcófago con escenas de la pasión de Cristo", donde toda la decoración de sus escenas columnadas narra el padecimiento y resurrección de Cristo.

La utilización de formas geométricas sencillas en los casos de Arjonilla, plantea la posibilidad de una factura exclusivamente visigótica, ya que su estilo fue muy utilizado por el pueblo germano en la elaboración de otras piezas constructivas como canceles, frisos o placas decoradas. Se trataría del primer estadio artístico del pueblo visigodo en la Península, previo a la posterior incorporación de formas antropomorfas y zoomórficas en la decoración. Las medidas de los sarcófagos, muy similares entre sí, no aportan datos relevantes, aunque sí confirman que estaban destinados a albergar los cuerpos de personas adultas, lo que se deduce de su longitud. Su elaboración en material pétreo ha permitido su buen estado de conservación en la actualidad, con la excepción del sarcófago de Alcaudete. 
No todos los sarcófagos visigodos contaron con la misma decoración, tales son los hallados en la necrópolis de Santagón ${ }^{24}$ (Viches, Jaén) o los encontrados en el yacimiento visigodo de la Legoriza (Salamanca), ${ }^{25}$ siendo realizados de una sola pieza, con paredes lisas y sin decoración alguna. La decoración de los casos de Arjonilla podría indicar el elevado estatus del difunto.

Como se ha podido observar a lo largo de este estudio, la elaboración de sarcófagos tardoantiguos en la Bética oriental no se produce de manera aislada, sigue la corriente escultórica de la época de otras regiones (citado el ejemplo de Córdoba). Habría que utilizar la localización de piezas tan monumentales no solo para su propio estudio, sino para poner en valor los yacimientos de los que provienen con el fin de fomentar el estudio de la casi olvidada etapa visigoda en la Andalucía oriental.

\footnotetext{
${ }^{24}$ Molinos, 1982: 306-312.

25 Gómez Gandullo, 2006: 217-236.
} 


\section{Bibliografía}

Beltrán J. y Rodríguez Oliva, P.:" Los Sarcófagos romanos de la Bética con decoración de tema pagano", Universidad de Málaga. (1999).

Bisconti, F. y Brandenburg. H. (dirs.): Sarcofagi tardoanticbi, paleocristiani e altomedievali.". Città del Vaticano, (2004), pp. 53-74.

Bovini, G.: "I Sarcofagi paleocristiani della Spagna", Città del Vaticano.

Cueves, A. (2007): "Los sarcófagos paleocristianos del sudeste español", Crónica del IV Congreso Arqueológico del Sudeste Español. Museo Arqueológico de Murcia, (1954), pp. 442-449.

Deichmann, F. W.: "Einfúhrung in die christliche Archaäeologie", Darmstadt. (1983).

Eichner, K.: "Die Produktionsmethoden der stadtrömischen. Sarkophagfabrik in der Blütezeit unter Konstantin”, Jarbuch für Antike und Christentum 24, (1981), pp.85-113.

Fita, F.: "Sarcófago de Écija", Boletín de la Real Academia de la Historia X, (1887), pp.267.

Flórez García, A.: "Los sarcófagos de Begastri. Catálogo actualizado, Antigüedady Cristianismo, no35-36, (2019), pp.235-248.

Franco Mata, Á.: "El sarcófago paleocristiano de Astorga en el Museo Arqueológico Nacional”, Argutorio año 22, nº43, (2020), pp. 4-10.

García García, M. A.: "La reutilización y destrucción de los sarcófagos romanos de Baetica durante la Edad Media", Romvla 3, (2004), pp.239-256.

García García, M. A.: "Los sarcófagos romanos de Andalucía, Corpus Signorum Imperii Romani", Pyrenae, vol.1, n³. (2006).

García García, M. A.: "Sarcófagos romanos decorados del siglo IV en el territorio andaluz: Enfoques y problemática vigente", SPAL, n 21, (2012), pp.183-193.

Grabar, A.: El primer arte cristiano (200-395), Madrid. (1985).

Gómez Gandullo, J. A.: "Avance sobre las excavaciones arqueológicas en el yacimiento de época visigoda de La Legoriza, San Martín de Castellar (Salamanca)", Zona Arqueológica $\mathrm{n}^{\circ} 8$, I. (Ejemplar dedicado a la investigación arqueológica de época visigoda en la Comunidad de Madrid), (2006), pp.217-236.

González Román C., y Mangas, J.: Corpus de inscripciones latinas de Andalucia, CILA VI, vol. III, Jaén, tomo I. Sevilla. (1991).

Immerzeel, M.: De sarcofaagindustrie rond 400. Het westelijke Middellandse Zeegebied. Leyden. (1996).

Kicker, J.: "Die christlichen sarkophage Spaniens Römische Mitteilungen", Römische Mitteilungen IV, (1887), pp.87-88.

Leal Lobón, M.: "El primer arte cristiano. El sarcófago de Junio Basso", Centro de Estudios Teológicos, (2011), pp.532-534.

Koch, G. y Sichtermann, H.: "Römische Sarkophage". München. (1982).

Koch, G.: "Frühchristliche Sarkophage". München. (2000).

Molinos Molinos, M.: "Excavaciones arqueológicas en la villa romana del Cuco (Santagón, Vilches, Jaén)", Actas del I CAEC, Jaén, Instituto de Estudios Giennenses, (1982), pp.306-312.

Palol, P.: "Hallazgos Hispano-Visigodos en la provincia de Jaén". Separata de la revista Ampurias, vol. XVII - XVIII, (1956),pp.286-292.

Palol, P.: Arqueología Cristiana de la España romana siglos IV-VI: Ladrillos con decoración en molde de la Bética; Madrid-Valladolid, (1967), p.276.

Revenga Domínguez, P.: "Sobre la historia de la historiografía artística", Saberes, vol. 3, (2005), pp. 1-23

Revenga Domínguez, P.: "Metodologías, interpretaciones y tributos de la Historia del Arte", en Palacio Prieto, J. L. (coord.): 90 años de cultura, México, UNAM, (2012), pp. 87-126. 
Rodà, I.: "Producción, materiales y circulación de sarcófagos en el Imperio Romano", en J. M. Noguera, E. Conde, El sarcófago romano. Contribuciones al estudio de su tipología, iconografía y centros de producción, Murcia, (2001), pp.51-78.

Sales y Ferre, M.: Estudios arqueológicos e Históricos. Necrópolis de Carmona. Funerales romanos y sus creencias acerca del alma y de la otra vida. Sarcófago visigótico de Écija. Excursión al Aljarafe. Madrid. (1887).

Schlunk, H.: "Die Sarkophage von Écija und Alcaudete", MM3, (1967), pp.119-151.

Schlunk, H.: "Un relieve de sarcófago cristiano de Barba Singilia", AESpA, XLII, (1968), pp. 166-182.

-Sotomayor, M.: Sarcófagos romano-cristianos de España, estudio iconográfico. Facultad de Teología, Universidad de Granada. (1975).

Vives, J.: Inscripciones romanas de la España romana y visigoda. Barcelona-Madrid. CSIC. (1942).

Ward Perkins, J.B.: "The role of the craftsmanship in the formation of the early Christian art", en Atti del Congresso Internazionale di Archeologia Cristiana. Roma 21-27 Settembre, I. Città del Vaticano, (1975), pp. 637-653. 